\title{
Putative Coiled-Coil Domain-Containing Protein 26
}

National Cancer Institute

\section{Source}

National Cancer Institute. Putative Coiled-Coil Domain-Containing Protein 26. NCI

Thesaurus. Code C134630.

Putative coiled-coil domain-containing protein 26 (109 aa, $\sim 13 \mathrm{kDa}$ ) is encoded by the human CCDC26 gene. This protein may play a role in the cellular response to retinoic acid. 